\title{
“ARE YOU AN ARAB OR A JEW?”' (SAMI SHALOM CHETRIT)-THE JEWISH-ARABIC POSITION IN HEBREW LITERATURE
}

\begin{abstract}
Mimi Haskin*
This article focuses on the return to Arab culture in contemporary Mizrachi literature. The paternalistic practices employed by the Ashkenazi authorities towards immigrants from Arab countries delegitimized the Arab culture and its language. This rejection by the hegemonic culture stemmed not only from a self-perception associating itself with the Western world, but also from the perception of Arabism as an enemy. Thus, although the hegemonic culture accepted Jews of Arab countries because of their Judaism, they were excluded due to their Arab roots. In contemporary Mizrachi literature, there is an increasing demand to reclaim and return Arab culture to the Israeli cultural arena, such as in the poetry of Sami Shalom Chetrit, Almog Behar, and Shira Ohayon. This movement towards the Arab sphere is conducted on several levels: A. as a counter-reaction to the oppression of all things Mizrachi; B. activities to present a more complete cultural gamut; C. a political call for reconciliation.
\end{abstract}

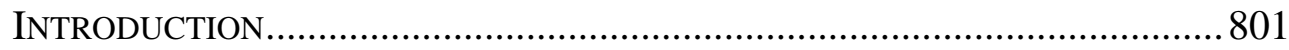

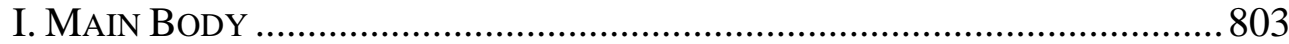

A. The First Plane-A Reaction against Oppression of the Mizrachi 803

B. The Second Plane upon Which the Turn to the Arab Space Is Made Present Is on That of a Whole Cultural Life and a Yearning to Belong 806

C. The Third Plane on Which the Jewish-Arab Position Operates Is the Political 808 CONCLUSION 810

\section{INTRODUCTION}

In this article, the author will present the Jewish-Arab space in contemporary Mizrachi literature in Israel. The melting pot policy requires being in line with the cultural hegemony and demands shedding the Diaspora to a large extent: taking a Hebrew name, abandoning mother tongue, adopting the local accent, turning one's back on the culture of one's

\footnotetext{
${ }^{1}$ Chetrit, Sami Shalom, 50-3 (2003).

* Dr., the head of the Department of Literature, Kibbutzim College, Tel Aviv, Israel. Research fields: The Jewish-Arab Conflict and Reflection in Literature.
} 
country of origin. The idea of rejecting the Diaspora, which arose in Eastern Europe, was foreign to the Jews in the Arab countries, who wanted to preserve their religion, customs and mother tongue. Mizrachi Jews were accepted into Zionist society because of their Judaism, but they were pushed to the margins because of their Arab characteristics. Their Jewish-Arab identity was rejected for two reasons: First, Zionism imagined itself as western and their Arab qualities contradicted this self-image and were perceived as foreign, inferior and undesirable. Second, this Arab nature was understood initially as enmity in order to allow exclusivity over the territory in the Land of Israel.

Dror Mishani ${ }^{2}$, author and researcher, maintains that, the encounter with Modern Hebrew, which was the property and principal conquest of the European Zionist movement, even before it conquered the country-was an important site for clarifying the Mizrachi's foreign nature and turning him into the other.

As a reaction, many Jews from the Arab countries who wanted full acceptance tried to assimilate, to relinquish their Arab identity and culture, and to fit in according to the norms of the hegemony.

Jewish artists in the Arab language were forced to decide between Arabic and Hebrew, between a natural identity and an artificial one and between withdrawal and integration.

The poet, Amira Hass ${ }^{3}$, described the process as "cutting the umbilical cord of the soul". The author Sami Michael ${ }^{4}$ confessed, "The boundary existing between the two peoples is, essentially, within my own inner self". The author, Shimon Ballas ${ }^{5}$ was the first to define himself as a Jewish-Arab author and said: "The essence of the definition Jewish-Arab is the language and the culture and also the customs, the foods, which are an addition to the Mizrachi life experience, but mainly it is the Arab language and culture (...) that we studied and read and loved (...) that is, Jews-Arabs, this is natural”. Ballas's position, which makes the Jewish-Arab identity present, operates as

\footnotetext{
${ }^{2}$ Mishani Dror, The Eastern as a Lingual Disorder, EAstern FACADE: Present Moving THRough Past ARABic Entanglement 86-7 (Yigal Nezri ed., Tel Aviv: Bavel Publications 2004) (Hebrew).

${ }^{3}$ Hess Amira, Arviyut, Yahadut, Tsiyonut: Ma'avakZehuyotba-YetsirashelYehude Iraq [Arabness, Jewishness, Zionism: A Struggle of Identities in the Literature of Iraqi Jews], SNIR, REUVEN 406 (Jerusalem: Ben-Zvi Institute 2005) (Hebrew).

${ }^{4}$ Michael Sami, Arviyut, Yahadut, Tsiyonut: Ma'avakZehuyotba-YetsirashelYehude Iraq [Arabness, Jewishness, Zionism: A Struggle of Identities in the Literature of Iraqi Jews], SNIR, REUVEN 321 (Jerusalem: Ben-Zvi Institute 2005) (Hebrew).

${ }^{5}$ Ballas Shimon, Revenge of the Arabic Interview with Shimon Ballas, BeHAR, Almog (Dec. 26, 2011) (Hebrew). Available at https://almogbehar.wordpress.com/?s=\%D7\%A0\%D7\%A7\%D7\%9E\%D7\%AA+\%D7\%94\%D7\%A2 \%D7\%A8\%D7\%91\%D7\%99\%D7\%AA.
} 
a factor interfering with the aloof western national likeness, and thus offers a true merging with Middle Eastern space. Literary criticism could not absorb the subversive space of merged spaces and languages and therefore, pushed Ballas's work to its margins and sinned against its complexity.

In contemporary Mizrachi literature, a voice is growing louder, that demands the presence of the Jewish-Arab identity in the Israeli cultural space. Haviva Pedaya ${ }^{6}$, poet and researcher, calls this process "awakening the sound box". Pedaya continues and proposes an image of a piano hiding a qanoon: "The two sounds are not external. Rather, one is internal and one is external. The sound on the outside, the shell, the representative sound is the piano. The sound on the inside, the one inside and unseen, is the sound of the qanoon, in order to be translated to the exterior, indeed, it must tear its strings, and it must absent itself in order to fit in”.

Turning to the Arab space operates on several levels:
A. a reaction against the oppression of Mizrachi culture;
B. nostalgia and yearning for a whole way of life;
C. a bridge to reconciliation with our Arab neighbors.

\section{MAIN BODY}

A. The First Plane-A Reaction against Oppression of the Mizrachi

Almog Behar ${ }^{7}$ tries to repeat the Arabic that was rooted in his family in previous generations, but the attempt did not succeed:

My Arabic is mute

Strangled in the throat

Cursing itself

Without uttering a word

Sleeping in the suffocating air of the shelters of my soul

Hiding

From family members

Behind the shutters of the Hebrew.

(...)

My Arabic is scared

Quietly impersonates Hebrew

Whispering to friends

With every knock on her gates:

\footnotetext{
${ }^{6}$ Pedaya Haviva, Present Moving through Past Arabic Entanglement, EASTERn FACADE 14-5 (Yigal Nezri ed., Tel Aviv: Bavel Publications 2004) (Hebrew).

${ }^{7}$ Behar Almog, My Arabic is Mute, WelLs’ ThiRst 15-6 (Tel Aviv: Am Oved Publishers 2008) (Hebrew).
} 
"Ahalan, ahalan, welcome."

And in front of every passing policeman

And she pulls out her ID card

For every cop on the street

Pointing out the protective clause:

"Ana min al-yahud, ana min al-yahud,

I'm a Jew, I'm a Jew."

And my Hebrew is deaf

Sometimes so very deaf.

Arabic has lost its voice, it is mute. It exists in curses and expressions assimilated by Hebrew and impersonating it. Arabic exists suffocated, hidden, and even from family members who deny it. There is no cultural sequence in the Mizrachi heritage. There are fragments, beginnings, and among them, the mother tongue has been forgotten. The presence of the Arabic is a subversive process because Hebrew is deaf. Therefore, Behar's poem makes us attend to the Arabic in its Hebrew transliteration: "Ana min al-Yahud". The Arabic words indicate a Jewish identity within them. The double identity comes from two directions: from Judaism and the “Arabism”.

Haviva Pedaya ${ }^{8}$, in her poem, "A man walking” coined the expression "ivrit" (a Hebrew plays on words - a misspelling of the word "Ivrit" meaning Hebrew and its misspelling implies "blindness") and she argues that, Hebrew is blind to its people, to its past, to Arabia:

(...)

In the meantime, I will prefer therefore to dwell within a word

Another home doesn't exist yet

It's doubtful that there ever was one

In my Hebrewness, my blindness, my Arabness

(...)

The struggle over Jewish-Arab identity, based on the Arab language, appears acutely in Mati Shmuelof's poetry", in his poem "And this is not a quote, this is a letter burned into my flesh":

The time has come to say the oppression has not ended

The land is not Middle Eastern

Rage asks to write an illiterate poem

Black out of white tunnels

\footnotetext{
${ }^{8}$ Pedaya Haviva, A Man Walking, BLOOD’s INK 15 (Tel Aviv: Hakibbutz Hameuchad Publishing 2009) (Hebrew).

${ }^{9}$ Shemuelof Mati, Poetry between Hazaz and Shemoelof (Tel Aviv: Yaron Golan Publisher 2006) (Hebrew).
} 
Words torn in prison

Arise unite for a revolt in language

We arose

Among the swords of racist letters that surrounded us

In transit camps lacking vowels

We the slaves of Homer and Bialik

Summon Mizrachi in opposition and a transition a sort of

Third possibility for poetry.

Identity is founded on language. The poem calls for a revolt in a style reminiscent of Bialik's "The Dead of the Wilderness"10: "We have arisen! We are here and we have ascended!" and that of the revolt in Yaakov Cohen's poem "Thugs"11. "We have risen, powerful youth/We have risen, we have returned thugs". The poem adopts the call to revolt in the style of the canonical literature, but this is a revolt against it and demands release from the restrictions of the hegemony to a poetic and cultural freedom. The language in which the poem calls for its establishment does not really exist. He calls for an illiterate poem, for a primal language, torn, without vowels. This language is furious, black, imprisoned in a remote racism. Written and read contemporary poetry is oppositional poetry and it serves as a transition on the path to establishing a whole identity. In the meantime, until then, this is poetry's third possibility.

The essence of Jewish-Arab identity is formulated in both an amusing and incisive manner in Sami Shalom Chetrit's poem " ${ }^{12}$ "A meeting with a likeable Jewish American":

Tell me, are you from Israel?

Yes, I'm from there.

Oh, and where do you live in Israel?

Jerusalem. I've lived there lately.

Oh, Jerusalem is a wonderful city.

Yes, it is indeed wonderful.

And you ... from the western part ... or from the eastern side ...

Aha, that's a hard question; it depends on who draws the map ...

You're funny, and you ... that is to say do you speak Hebrew?

Yes, of course.

I mean it's your mother tongue.

\footnotetext{
${ }^{10}$ Bialik Chaim Nachman, The Dead of the Wilderness (“MeteyMidbar”), PoEMs 218-26 (Avner Holtzman ed., Tel Aviv: Dvir 1901, 2004) (Hebrew).

${ }^{11}$ Cohen Yaakov, Thugs ("Biryonim"), 12 HashiLOACH 565 (1903) (Hebrew).

${ }^{12}$ Chetrit Sami Shalom, A Meeting with a Likeable Jewish American, SHIRIMBEASHDODIT (POEMS IN AsHDODiAN) 50-3 (Tel-Aviv: Andalus Publishers 2003) (Hebrew).
} 
Not exactly. My mother tongue is Arabic, but today she speaks fluent Hebrew.

(...)

Pardon me for the nosy question, I simply have to ask it, are you a Jew or an Arab?

I'm a Jew-Arab.

You're funny.

No, I am being serious.

A Jew-Arab?! I've never heard that before.

It's simple: just like you say Jewish-American. Here, try to say JewEurope.

Jew-Europe.

And now say Jew-Arab ...

There's nothing to compare, Jew-Europe is something else.

Why?

Because “Jew” doesn't go with “Arab”, it simply doesn’t go. It doesn’t even sound right.

\section{(...)}

The poem reveals the dichotomy and opposition existing in relation to Arab culture. According to hegemonic norms, a double cultural identity can be established only in the case of a European culture. Hebrew culture recognizes its European roots, and is even proud of them. However, it has refused to accept the Arab quality existing in the world of most of its citizens. This Arab quality doesn't sound right. Chetrit reveals that, the exclusion of cultures of origin was not a result of rejecting the Diaspora per se, but rather it is a rejection of the Arabic Diaspora. He sarcastically and incisively challenges this position as a reaction against Mizrahi oppression.

B. The Second Plane upon Which the Turn to the Arab Space Is Made Present Is on That of a Whole Cultural Life and a Yearning to Belong

In Chetrit's poem ${ }^{13}$, there is another part that attacks the issue from a nostalgic direction, the nostalgia and yearning for wholeness:

Only when I left, did I remember

That I didn't mean at all to get emotional that way

And basically, I wanted to tell her

That my first babysitter in Morocco was a Muslim girl

And I have her black and white photo in an old album

On the checkerboard courtyard floor

\footnotetext{
${ }^{13}$ Chetrit Sami Shalom, A Meeting with a Likeable Jewish American, THERE 53 (2003).
} 
And when I was a boy a new immigrant a knife-wielding Moroccan

I tried uselessly to recreate a conversation of a boy

With his babysitter in Moroccan Arabic.

And a mother who when you remind her says:

Ah hai aliha shehal khant tihbak

How much she loved you, she never left your side for a minute.

The yearning figure of the Muslim babysitter appears here, which also appears in "Iiya" 14 , Ballas's novella. The Mizrahi immigrant remembers with longing the connection with the woman who cared for him. That is a primal connection, of mother and son, which consists of bodily contact and a sensory mixture. However, the speaker cannot recreate their conversation because the language has been lost to him by the culture's coarse amputation. On the other hand, his mother, for whom the language is still alive on her tongue, tells him in Arabic: "How much she loved you, she never left your side for a minute". In his poem, it remains for him to make the Arabic present, if only in its Hebrew transliteration. That is an Arabic bound in love and the sense of deep identity that it provides. That is an Arabic, which shouldn't only be spoken about, but also, must be spoken and felt. It is interesting that, the nostalgic space is located on the checkerboard floor of the courtyard. Not a monolithic courtyard, not a single-color courtyard, not a one-dimensional courtyard, but a checkered one, complex.

The longing for the wholeness of the lost identity and attempts to recover it, appear in an interesting manner in Shira Ohayon's poem ${ }^{15}$, "Last/Sufi Station":

Screw me in Moroccan

In the dark Awad thani (once more)

Send me to the hot desert

Of your fingers playing on my body

The melody of hashish

To a bluesy rhythm

The soul of the holy ones will perform a tikkun (repairing the world)

In the morning we'll have goat cheese

English tea

A Bach fugue

(While the couscous was steaming)

Both of us refugees

Members of the lost generation

Eternal lost wanderers

\footnotetext{
${ }^{14}$ Ballas Shimon, Iiya, Отот STAv 9-50 (Or Yehuda: Zmora-Bitan 1992) (Hebrew).

${ }^{15}$ OHAYON SHIRA, LAST/SUfi StATION (2013) Available at http://hamizrahit.blogspot.co.il.
} 
Searching for The Ring of the Dove,

Tawk Al-Hamamah

Racing together on a chariot of fire

To the worm home

To the great light.

The poem opens with a penetrating call expressing gender liberation: "Screw me". But immediately, this call takes on an ethnic tone: "Screw me in Moroccan". The desire is for a deep intimate encounter in which the physical and cultural are interwoven. Eroticism is empowered by virtue of the common mother tongue, which naturally constructs sharing and deep understanding. The invitation to the act of love is made in Moroccan Arabic and the use of this language, mixed with Hebrew, the use of bilingualism is an integral part of the enchanted experience in the poem. The harmony consists of a blend of several cultures: the Moroccan language, Bach's music, the food of the Moroccan kitchen, Sufi mysticism, and bodily love enunciated in the original language. Ohayon suggests a personal, physical, ethnic, social, and political yearned-for wholeness, interweaving them all. The poem is titled "Last Station" in its literal sense, as well as "Sufi Station" (depending on how the Hebrew word is read- "sofit" or "sufit") in the sense of Islam's mystical movement. Sufi Islam is an ideological movement, which places emphasis on love and desire to reach the source. The speaker characterizes the lovers in the poem as lost wanderers motivated by Sufi energy, searching for a sense of an absent home. The inspiration for the longed-for love is described in The Ring of the Dove, an Arabic composition from the 11th century, in which love, its causes, and its progression are described. Ali Ibn Hazm the Andalusian, who was a theologian and philosopher, wrote this composition. The inspiration for the erotic encounter and search for identity is a canonical Arab source, unknown in the Israeli cultural hegemony, but for the wandering writer, it has the power to provide wholeness and the return of her identity.

\section{The Third Plane on Which the Jewish-Arab Position Operates Is the Political}

Plane according to this outlook, Arab Judaism, in its essence, does not receive the attitude of enmity toward the Arabs and therefore, it can offer a bridge of reconciliation and peace. In the 1950s, Sasson Somech, Shimon Ballas, and David Zemach had already established "The circle advocating Arabic literature in Israel”, whose objective was to create a bridge between Hebrew and Arabic literature and to act toward mutual understanding, in 
spite of the blood-soaked borders.

A daring example of that is Zvi Ben-Dor Benite's story "The Treasure in Bisan-as it occurred, because it was told to me and as it will occur" 16 . The story was published in a special edition of the journal Sedek, which dealt with the idea of the return. This journal is issued by Zochrot and its objective is to raise awareness among Israelis of the Nakba and taking responsibility for it. Sedek, true to its name (Crack), presents cultural opportunities that only exist in a narrow crack, on the margins of Israeli culture. Ben-Dor Benite's story imagines the Palestinian return, which brings a cultural and economic flowering to the region. The story imagines crossing the barrier that politics has delineated as impassable. According to Martha Nussbaum ${ }^{17}$, in her book Poetic Justice, the ability of imagination which permits approaching one's fellow, is the essence of the strength and the purpose of literature.

The story's focus describes a Jewish family who lives in Mosul, Iraq. Following the 1948 War, the family is forced to move from Mosul to Palestine. At the same time and in the same context, the story describes the uprooting of the Palestinians in Bisan and their arrival as refugees in Mosul. Both groups of displaced persons have strong longing for their roots. The parallel between the displaced persons creates similarity and permits empathy. A mixture of Palestinian and Jewish identities heightens the emotional and national mirror image until every barrier is removed. This mixture pictures national separation as a self-interested invention contradicting the real connection that was and that can still exist between Jews and Arabs. In the spiritual world of the story's heroes, Jews and Arabs live together and share a language, country and culture. The only difference is religion. Even the wars cutting into living flesh and splitting nations apart cannot disrupt the imprint of this closeness.

The present time of the story is in 1949, in Mosul, on Passover eve. While reading during the Seder, "This is the bread of affliction”, three Iraqi soldiers who fled the battles in Palestine arrive at the family's home. The soldiers tell about the Jewish victory in Palestine and this creates some embarrassment for the hosts and a tentative wedge between them and their guests. Nevertheless, the news does not have the power to create a rift in the natural fraternity existing between guests and hosts, Arabs and Jews. The

\footnotetext{
${ }^{16}$ Ben-Dor Benite Zvi, The Treasure in Bisan-as It Occurred, Because It was Told to Me and as It Will Occur, SedeK-A Journal on the Ongoing NAKBA. AwdA. IMAgined TESTIMONIES FROM Potential Futures (Zochrot \& Pardes 2013). (Hebrew and Arabic).

${ }^{17}$ Nussbaum Martha, Poetic Justice: the Literary Imagination and Public Life (Boston, Massachusetts: Beacon Press 1995).
} 
hopelessness of the war taking place in Palestine is heightened by the analogy of the butchers and the butchered from the liturgical poem, "One only kid", sung that evening.

On the other hand, the arrival of Mosul's Jewish refugees to the State of Israel is described as traumatic: "The Mosul Jews found themselves cut into quarters. One quarter in Jerusalem, one quarter in Tirat HaCarmel, one quarter in Tiberias, and one quarter in Bisan.” The splitting apart of the family intensifies the sense of displacement and expulsion from paradise. Life in Israeli Beit She'an is insubstantial and hard. A livelihood is in grueling public works. The Jewish immigrants don't experience the paradisiacal Bisan as described from a distance. This is life in a miserable and remote town, according to the image of the place in its Israeli years. The lull from the hard-pressed reality only occurs during times of unification: family unification, and the unification of Arabic-Jewish space-when the Jewish family goes to the market in Jenin where it's possible "to breathe Arabic air" and the Sachne where it's possible to bathe together with the children of neighboring Jenin. The story opposes the monolithic attitudes of enmity that had become secured in the prevalent national consciousness, like a fated decree that never wears out.

The longing for the past is what creates the rumor about the treasure hidden, as it were, in Bisan. This is a treasure made up of stories, memories and nostalgia, which has the power to provide for future longings and to arouse the desire for return.

From this point, the story abandons its hold in historical evidence and sails on into a utopian future. In an aspired to and imagined future, there will be noise, cosmic upheaval undermining the existing order, eroding the foundations of the state and allowing a Palestinian return to the country, to Bisan, to a world of economic, academic and cultural flowering, and especially, to a world of reconciliation.

\section{CONCLUSION}

Contemporary Mizrachi literature opens new possibilities for becoming integrated into the Middle East, in both cultural and political terms. Against the backdrop of having been marginalized, Mizrachi creation has developed an independent voice that is not beholden to norms dictated by the hegemony.

This voice has risen from a cry of oppression and has come to propose bridges of national reconciliation between Israel and its neighbors.

The force linking contemporary Hebrew Mizrachi creation and Arab 
culture is the force of the Arabic language, the mother tongue of the Jews who came from the Arab states. The children of the second generation, whose works have been presented in the article, have tried to reconstruct the mother tongue, to make it present in their works and to experience the cultural wholeness that it bears.

Because of this link, there is the possibility for political and national reconciliation between peoples in strife. 